Chirurgia (2018) 113: 772-779

No. 6, November - December

Copyright $\odot$ Celsius

http://dx.doi.org/10.21614/chirurgia.113.6.772

\title{
D2 Lymphadenectomy for Gastric Adenocarcinoma: Long-term Results and the Impact of Surgeon Experience on the Survival Rates
}

\author{
Stefan Tudor', Traian Dumitrascu ${ }^{1,2}$, Mircea Manuc ${ }^{2,3}$, Bogdan Trandafir', Mihnea Ionescu', Irinel Popescu ${ }^{1,4}$, \\ Vlad Herlea ${ }^{4,5}$, Catalin Vasilescu ${ }^{1,2}$ \\ 'Department of General Surgery, Fundeni Clinical Institute, Bucharest, Romania \\ 2"Carol Davila" University of Medicine and Pharmacy, Bucharest, Romania \\ ${ }^{3}$ Department of Gastroenterology and Hepatology, Fundeni Clinical Institute, Bucharest, Romania \\ 4"Titu Maiorescu" University, Bucharest, Romania \\ ${ }^{5}$ Pathology Department, Fundeni Clinical Institute, Bucharest, Romania
}

Corresponding author:

Professor Catalin Vasilescu

Department of General Surgery

Fundeni Clinical Institute,

258 Fundeni Street, Bucharest, Romania

E-mail: catvasilescu@gmail.com

\section{Rezumat}

Limfadenectomia D2 în tratamentul adenocarcinomului gastric: rezultatele pe termen lung și impactul experienței chirurgului asupra supraviețirii

Introducere: Chirurgia reprezintă componenta de bază în tratamentul cu viză curativă al adenocarcinomului gastric. Studiul îşi propune să evalueze comparativ rezultatele postoperatorii imediate şi pe termen lung după limfadenectomia D1 şi D2. În plus, este evaluat impactul numărului de gastrectomii radicale cu limfadenectomie D2 per chirurg asupra supraviețirii pe termen lung în adenocarcinomul gastric.

Material şi metodă: În perioada 1997 - 2010 au fost efectuate un număr de 773 gastrectomii radicale pentru adenocarcinom gastric (325 pacienți cu limfodisecție D1 şi 448 pacienți cu limfodisecție D2). Rezultate: $\mathrm{Nu}$ au fost constatate diferențe semnificative statistic între limfadenectomia D1 şi D2 în ceea ce priveşte rata globală de complicații postoperatorii (16,3\% pentru grupul D1 vs. 18,8\% pentru grupul D2, $p=0.39$ ). Totuşi, în grupul pacienților cu limfadenectomie D2 rata fistulei pancreatice a fost semnificativ statistic mai mare decât în grupul pacienților cu limfadenectomie D1 (3,2\% pentru grupul D1 vs. 7,9\% pentru grupul D2, $\mathrm{p}<0.001$ ). Mortalitatea postoperatorie a fost semnificativ statistic mai mare în grupul cu limfadenectomie D1 față de grupul cu limfadenectomie D2 (8,9\% pentru grupul D1 vs. $2,9 \%$ pentru grupul D2, p < 0.001). Rata de 
supraviețuire la 5 ani a fost semnificativ statistic mai bună în grupul cu limfadenectomie D2 față de grupul cu limfadenectomie D1 (supraviețuire mediană de 18 luni în grupul D1 vs. 60 luni în grupul $\mathrm{D} 2, \mathrm{p}<0.001)$. O corelație semnificativă statistic $(\mathrm{p}=0.005, \mathrm{r}=0.571)$ a fost observată între supraviețuirea globală şi numărul de limfodisecții D2 efectuate de fiecare chirurg.

Concluzii: Limfadenectomia D2 în adenocarcinomul gastric este asociată cu o rată de supraviețire pe termen lung semnificativ mai bună comparativ cu limfadenectomia D1, dar cu prețul unei rate mai mari a fistulei pancreatice postoperatorii. Totuşi, nu s-a semnalat o creştere a mortalității postoperatorii în grupul cu limfadenectomie D2. Gastrectomia radicală cu limfadenectomie D2 trebuie efectuată în centre chirurgicale cu volum mare, de către chirurgi cu experiență.

Cuvinte cheie: cancer gastric, gastrectomie radicală, limfadenectomie D2, complicații postoperatorii, supraviețuire pe termen lung

\section{Abstract:}

Background: Surgery is the main component of the multimodality treatment of gastric cancer (GC). The present study aims to comparatively assess the early and long-term outcomes after D1 and D2 lymph node dissection. Furthermore, the impact of surgeon case-load on the long-term survival after D2 gastrectomies is also explored.

Methods: A number of 773 patients with curative-intent surgery for GC adenocarcinoma (1997 - 2010: 325 patients with D1 lymphadenectomy, 448 patients with D2 lymphadenectomy) were included.

Results: No statistically significant differences of overall morbidity rates were observed between the D1 and D2 groups of patients (16.3\%for D1 group vs. $18.8 \%$ for D2 group, $p=0.39$ ). However, statistically significant higher rates of post operative pancreatic fistulae rates were observed in the D2 group of patients $(3.2 \%$ for D1 group vs. $7.9 \%$ for D2 group, $\mathrm{p}<0.001)$. Interestingly, statistically significant higher rates of mortality were observed for the D1 group of patients ( $8.9 \%$ for D1 group vs. 2.9\% for D2 group, $\mathrm{p}<0.001)$. The 5-year survival rate was statistically significant higher in the D2 group of patients (median overall survival time of 18 months for D1 group vs. 60 months for D2 group, $\mathrm{p}<0.001)$. A statistically significant correlation $(\mathrm{p}=0.005, \mathrm{r}=0.571)$ was observed between the overall survival time and the number of D2 lymphadenectomies performed by each surgeon.

Conclusions: D2 lymph node dissection is associated with statistically significant improved longterm survivals at the expense of higher postoperative pancreatic fistulae rates, compared to D1 surgery. However, no increased mortality rates were observed in the D2 group of patients. D2 radical gastrectomies should be performed in high-volume centers by high case-load surgeons.

Key words: gastric cancer, radical gastrectomy, D2 lymph node dissection, postoperative complications, survival

\section{Introduction}

Despite a decreasing incidence and the improvement of diagnostic techniques, gastric cancer (GC) remains the fifth most common malignancies and the third cause of cancerrelated death worldwide for both sexes (1). However, GC recognizes geographical and gender disparities. Thus, CG is more frequently encountered in men, and the highest incidence of GC was observed in Eastern Asia and Eastern Europe (1). In Eastern Europe, the age-standardized rate per 100,000 of GC incidence is 17.1 among males, and 7.5 among females (1).

In Romania, the estimated age-standardized rate per 100,000 of GC incidence for the year 2018 is 18.8 among males and 7.3 among 
females (2). Thus, the estimated new GC cases in 2018 for Romania are 35,200, while the estimated number of GC deaths is 30,200 (2). The close gap between the new GC cases and the annual GC deaths shows that most GC patients in Romania are diagnosed in advanced stages when a curative approach is not possible.

Surgery is the main component of the multimodality treatment of GC adenocarcinoma for both curative-intent and palliative settings (3). Gastrectomy with adequate lymph node dissection represents the single hope for a cure in patients diagnosed with gastric adenocarcinoma (4).

The question of how extensive should a gastrectomy be for treatment of GC received conflicting answers in time (4). However, proper lymph node dissection is widely considered a critical component of curativeintent surgery for GC (5). It is the merit of the Japanese School of Gastric Surgery to show the long-term oncological benefits of an extended lymph node dissection (i.e., more than D1) in GC surgery (6). The Japanese Gastric Cancer Association also defined the D1 and D2 gastrectomies (3). Thus, D2 gastrectomy is considered the standard surgical approach of curative-intent surgery for locally advanced GC in Eastern Asia for a long time (3).

The adoption of D2 lymph node dissection in GC surgery in Western countries did not follow the enthusiasm of the Eastern Asia surgical teams. Initial experiences provided by randomized trials with Western patients did not show any survival benefits of D2 lymph node dissection over D1 surgery in GC $(7,8)$. Moreover, statistically significant increased morbidity and mortality rates were associated with D2 surgery in those trials $(7,8)$. More recent data with Western patients have shown the potential survival benefit of D2 lymph node dissection for only a subgroup of patients with GC and lymph nodes metastases $(9,10)$. Nevertheless, a reevaluation of the Dutch trial published in 2010 showed significant higher long-term survivals after extended lymphadenectomy compared to D1 surgery, with higher loco-regional recurrences in the D1 group of patients (11). Thus, nowadays D2 gastrectomy is considered the standard of curative-intent surgery of GC in most experienced Western surgical centers.

In our hospital, an extended lymph node dissection in curative-intent surgery of GC was adopted in an early setting (12-15), compared to other European surgical centers, and the oncological benefits of D2 gastrectomy were previously demonstrated in our initial experience (15).

The present study is an updated relatively extensive experience with GC surgery of Western patients and aims to comparatively assess the early and long-term outcomes after D1 and D2 lymph node dissection. Furthermore, the impact of surgeon case-load on the longterm survival after D2 gastrectomies is also explored.

\section{Patients and Methods}

A total number of 2000 patients diagnosed with malignant gastric tumors underwent surgery in the Department of General Surgery of Fundeni Clinical Institute, between 1997 and 2010. Data were obtained from medical and surgical records, surgical protocols, pathology reports, and the survival data were provided by the Population Evidence Department.

Thus, a total number of 1807 patients diagnosed with gastric adenocarcinoma were included in this study; patients with the final pathology of gastric lymphoma (157 cases) and gastric stromal tumor (36 cases), were excluded. The cases of gastric stump carcinoma were also excluded.

A number of 1034 patients underwent palliative procedures: palliative gastrectomy 389 patients and non-resectional procedures (i.e., internal by-pass, jejunostomy, gastrostomy or explorative laparotomy) - 645 patients.

A number of 773 patients underwent curative-intent surgery for GC adenocarcinoma: 325 patients have had a D1 lymphadenectomy, while 448 patients have had a D2 lymphadenectomy. The median age of patients was 64 years (range, 12 - 98 years), with males: females' ratio of $2: 1$. 
It is worth mentioning that during the analyzed period, a number of 28 robotic or laparoscopic-assisted gastrectomies were performed. These minimally-invasive procedures were carried out by a single main operator (CV). A retrospective analysis performed on patients undergoing minimally-invasive curative-intent gastrectomies regarding operative and postoperative outcomes, as well as long-term survival data were previously reported (16-19).

The surgical technique of D2 lymphadenectomy was previously described elsewhere $(15,20)$.

\section{Statistical Analysis}

The data are expressed as the number (percentage) for categorical variables and were analyzed using the Graph Pad Prism 8 (GraphPad Software Inc. CA, USA). Fisher's exact test was used to compare the categorical variables between the groups. Spearman's rho correlation coefficient was used for the categorical variables. The median overall survival was estimated using the Kaplan-Meier curves. The comparisons between the groups were made using the log-rank test. The overall survival time was considered the time from surgery to death occurrence or last follow-up (December 1,
2015). In all the tests that were used, the confidence interval was $95 \%$ ( $p$-value $<0.05$ ).

\section{Results}

\section{Postoperative Morbidity and Mortality}

No statistically significant differences of overall morbidity rates were observed between the D1 and D2 groups of patients (16.3\% for D1 group vs. $18.8 \%$ for D2 group, $p=0.39$ ), as shown in Table 1. However, statistically significant higher rates of postoperative pancreatic fistulae rates were observed in the D2 group of patients, compared to the D1 surgery $(7.9 \%$ for D2 group vs. $3.2 \%$ for D1 group, $p<0.001$ ). No statistically significant differences between the groups were observed for the anastomotic leak, hemo-peritoneum or pulmonary complications rates, as shown in Table 1.

Interestingly, statistically significant higher 30-day mortality rates were observed in the group of patients with D1 gastrectomies, compared to the D2 group (8.9\% for D1 group vs. $2.9 \%$ for D2 group, $\mathrm{p}<0.001$ ), as shown in Table 2.

\section{Overall Survivals}

The 5-year survival rate was statistically

Table 1. The 30-day postoperative morbidity in 773 patients with curative-intent gastrectomies for gastric adenocarcinoma

\begin{tabular}{lccc}
\hline Complications & $\begin{array}{c}\text { D1 lymphadenectomy } \\
\mathbf{n}=\mathbf{3 2 5}\end{array}$ & $\begin{array}{c}\text { D2 lymphadenectomy } \\
\mathbf{n}=\mathbf{4 4 8}\end{array}$ & P value \\
\hline Overall complications & 53 patients $(16.3 \%)$ & 84 patients $(18.8 \%)$ & $0.39^{\dagger}, \mathrm{ns}$ \\
\hline Anastomotic fistula & 11 patients $(3.5 \%)$ & 17 patients $(3.9 \%)$ & $0.84^{\dagger}, \mathrm{ns}$ \\
\hline Pancreatic fistula & 10 patients $(3.2 \%)$ & 35 patients $(7.9 \%)$ & $<0.001^{\dagger}$ \\
\hline Hemoperitoneum & 11 patients $(3.5 \%)$ & 14 patients $(3.2 \%)$ & $0.83^{\dagger}, \mathrm{ns}$ \\
\hline Pulmonary complications & 21 patients $(6.5 \%)$ & 18 patients $(4 \%)$ & $0.13^{\dagger}, \mathrm{ns}$ \\
\hline
\end{tabular}

'Fisher's exact test, two-tailed

Table 2. The 30-day postoperative mortality in 773 patients with curative-intent gastrectomies for gastric adenocarcinoma

\begin{tabular}{lcc}
\hline Type of surgery $^{\dagger}$ & $\begin{array}{c}\text { Deaths recorded } \\
\text { (No.) }\end{array}$ & $\begin{array}{c}\text { Deaths recorded } \\
\text { (\% of total number) }\end{array}$ \\
\hline D1 lymphadenectomy & 29 patients & $8.9 \%$ \\
\hline D2 lymphadenectomy & 13 patients & $2.9 \%$ \\
\hline${ }^{\top} P 0.001$ with Fisher's exact test, two-tailed & &
\end{tabular}


Table 3. The survival data in 773 patients with curative-intent gastrectomies for gastric adenocarcinoma

\begin{tabular}{|c|c|c|}
\hline $\begin{array}{l}\text { Follow-up } \\
\text { (patients alive at) }\end{array}$ & $\begin{array}{l}\text { D1 lymphadenectomy } \\
\qquad n=325\end{array}$ & $\begin{array}{c}\text { D2 lyphadenectomy } \\
n=448\end{array}$ \\
\hline 3-year & $32.07 \%$ & $55.05 \%$ \\
\hline 5-year & $21.06 \%$ & $38,82 \%$ \\
\hline Median overall survival time ${ }^{\dagger}$ & 18 months & 60 months \\
\hline
\end{tabular}

significant higher in the D2 group of patients, compared to D1 surgery (median overall survival time of 18 months for D1 group vs. 60 months for D2 group, p < 0.001) (Fig. 1), as shown in Table 3. Thus, $38.82 \%$ of patients with D2 lymphadenectomy were alive after 5 years from surgery, while only $21.06 \%$ of patients with D1 lymphadenectomy were alive after 5 years from surgery $(\mathrm{p}<0.01)$.

It is worth mentioning that there were no statistically significant differences between the groups regarding clinical and pathological factors or disease stages (data not shown). Noteworthy, statistically significant differences of survival times between D1 and D2 groups were observed for stages IIA and IIB (27 vs. 138 months and 16.5 vs. 74 months, respectively, $\mathrm{p}$ values $<0.05)$.

\section{The Impact of Surgeon Case-load on Overall Survivals}

The impact of surgeon case-load on the longterm survival after radical surgery for GC was also analyzed. The surgeons were classified according to the numbers of D2 lymphadenectomies performed and were divided into two groups: the first group consisted of surgeons with more than 100 D2 lymphadenectomies performed $(n=2)$; the second group included the remaining surgeons $(n=20)$. A total number of 220 D2 lymphadenectomies were performed by surgeons from the first group, while the second group of surgeons performed the remaining 228 procedures. The 5-year overall survival rates were significantly higher in the first group, compared to the second group of surgeons (median overall survival time of 78 months vs. 43 months, $\mathrm{p}<0.05$ ), as shown in Fig. 2 .

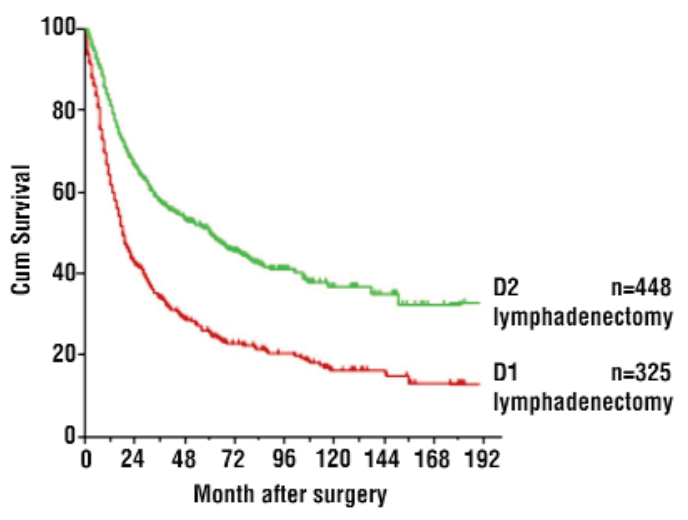

Figure 1. The comparative Kaplan-Meier overall survival curves in the D1 and D2 group of patients

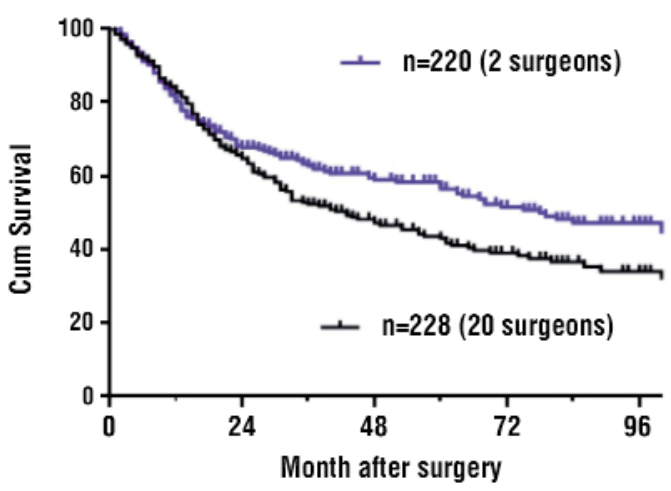

Figure 2. The comparative Kaplan-Meier overall survival curves in the group of surgeons with more than 100 D2 radical gastrectomies and the group of surgeons with less than $100 \mathrm{D} 2$ radical gastrectomies

A statistically significant correlation ( $p=0.005, r=0.571$ ) was observed between the overall survival time and the number of D2 lymphadenectomies performed by each surgeon.

\section{Discussions}

There was a constant inconsistency between the high morbidity rates associated with extended lymph node dissection and no evidence of a long-term survival benefit reported by two main European randomized trials $(7,8)$ and good long-term survival rates reported by the observational studies in European highvolume centers after extended lymph node dissection (21-24). The explanation for these 
differences could be that in both trials there was a high number of participating centers with few experiences in performing an extended lymph node dissection. Furthermore, in the extended lymph node dissection group of patients there were many associated distal pancreatectomies or splenectomies which could be the cause for the high complication rates (25).

Initially, a D2 gastrectomy associated mandatory splenectomy and distal pancreatectomy (26). Nowadays, it was demonstrated that a safe D2 lymph node dissection could be performed without splenectomy and distal pancreatectomy, with the same oncological benefits but without associated morbidities of the two surgical procedures $(27,28)$.

Furthermore, a recent meta-analysis has shown no differences of long-term oncological outcomes in patients with radical gastrectomies for GC with and without splenectomy, but splenectomy was associated with statistically significant increased early morbidity rates (29).

Assessment of quality of D2 lymph node dissection in GC is an important issue. Thus, it was suggested that a proper D2 lymph node dissection should be assessed not only by the surgeon but also by the pathologist (30). However, it is worth mentioning that many factors influence the number of retrieved lymph nodes. A recent meta-analysis has shown that ex vivo lymph node dissection performed by the surgeon is associated with increased number of harvested lymph nodes and thus there is a potential for a better staging of the disease and a more precise therapy (31).

The high rate of postoperative complications was considered an argument against an extended lymph node dissection in GC surgery in many Western surgical centers for a long time. However, the high morbidity and mortality rates associated with D2 lymph node dissection in the Dutch trial (7) appear to be related to low expertise in radical gastrectomy in many surgical centers included in the study. Thus, postoperative morbidity and mortality rates after GC surgery are influenced by the technical skills of the surgeon $(32,33)$. Recent data with Western patients have shown no significant differences of morbidity and mortality rates between D1 and D2 gastrectomies $(9,10)$. Nevertheless, radical gastrectomies with extended lymph node dissection should be performed in high-volume centers by experienced surgeons.

Gaining expertise in D2 gastrectomies remains an important issue, particularly in Western surgical centers where the number of patients with GC suitable for a curative-intent surgery is relatively limited. It was suggested that a surgeon should perform at least 15 to 25 D2 gastrectomies to minimize bias due to surgeon-related factors $(34,35)$.

In a single center randomized controlled trial, $\mathrm{Wu}$ and co-workers demonstrated the survival benefits for gastric cancer offered by an extended lymph node dissection by well trained, experienced surgeons (36).

Surgeon case-load may impact the postoperative outcomes after radical gastrectomies for GC. Thus, surgeon case-load was associated with postoperative mortality after radical gastrectomies for GC in few studies, as two reviews have shown $(37,38)$. Two systematic reviews published in 2012 and 2017 did not identify any correlation between hospital volume of gastrectomies and postoperative complications in the most substantial part of reported studies $(37,38)$. However, a higher hospital volume was associated with lower mortality rates $(37,38)$. The assessment of the impact of hospital volume on the long-term survival of patients with radical gastrectomies for GC reached conflicting results. Thus, few studies associated a high-volume hospital with statistically significant better long-term survivals, while others did not $(37,38)$.

Nevertheless, a recent Dutch study has shown that patients with GC who underwent radical gastrectomies in high-volume centers have a statistically significant increased chance to have a D2 lymph node dissection, negative resection margins, and better overall survivals, compared to low-volume hospitals (39).

As it was previously mentioned, the data of the literature regarding the impact of D2 lymph node dissection on outcomes after radical gastrectomy for $\mathrm{GC}$ reached conflicting 
conclusions. Thus, two meta-analyses published in 2009 and 2011 have concluded that D1 lymph node dissection is associated with significantly fewer anastomotic leaks, postoperative complication, and 30-day mortality rates, without any detrimental oncological outcomes, compared with the D2 surgery $(40,41)$. However, meta-analyses published in 2013 and 2014 showed that D2 lymph node dissection has oncological benefits over D1 surgery when the spleen and pancreas are preserved, and the surgery is done safety (42) and for T3 patients and advanced nodal stage (43).

The present study has shown no statistically significant differences of overall postoperative complications (including anastomotic leaks) and mortality rates between D1 and D2 gastrectomies, as previous studies have shown $(9,10)$. However, statistically significant higher rates of postoperative pancreatic fistulae rates were observed in the D2 group of patients of the present study, compared to the D1 surgery. Although, it is a retrospective study, the present one has shown on a relatively large number of Western patients the oncological superiority of D2 lymph node dissection over D1 surgery in GC.

Noteworthy, the present study has shown that the surgeon experience is not only associated with decreased rates of postoperative complications but also with a statistically significant better overall survivals. Several previous studies explored the impact of surgeon case-load on the long-term survival after radical gastrectomies for GC, as a review has shown (37). Only two studies have associated a high case-load surgeon with statistically significant better overall survivals $(33,44)$. Thus, surgeons with more than 72 procedures have had the highest survival rates after radical gastrectomies for GC (44). In the present study, it appears that surgeons with more than 100 procedures have the highest survival rates after radical gastrectomies for GC.

\section{Conclusions}

A D2 lymph node dissection should be the standard approach of curative-intent surgery for resectable locally advanced GC in Western patients. In high-volume centers, D2 gastrectomies can be safely performed, and are not associated with increased overall morbidity and mortality rates, compared to D1 surgery. However, increased rates of postoperative pancreatic fistulae rates should be expected when a D2 lymph node dissection is performed, compared to D1 surgery. Furthermore, D2 lymph node dissection is associated with statistically significant improved long-term survivals, compared to D1 surgery. Noteworthy, high caseload surgeons are associated with statistically better oncological outcomes, compared to low case-load surgeons. Thus, D2 radical gastrectomies should be performed in high-volume centers by high case-load surgeons.

\section{Conflicts of Interest}

The authors declare no conflicts of interests.

\section{Authors' Contributions}

Stefan Tudor, Traian Dumitrascu and Mircea Manuc share the first authorship.

\section{References}

1. Bray F, Ferlay J, Soerjomataram I, Siegel RL, Torre LA, Jemal A. Global cancer statistics 2018: GLOBOCAN estimates of incidence and mortality worldwide for 36 cancers in 185 countries. CA Cancer J Clin. 2018:68(6):394-424.

2. Ferlay J, Colombet M, Soerjomataram I, Dyba T, Randi G, Bettio M, et al. Cancer incidence and mortality patterns in Europe: Estimates for 40 countries and 25 major cancers in 2018. Eur J Cancer. 2018;103:356-87.

3. Japanese Gastric Cancer A. Japanese gastric cancer treatment guidelines 2014 (ver. 4). Gastric Cancer. 2017;20(1):1-19.

4. Sue-Ling H. Radical D2 gastrectomy for cancer. The case of D2 resections. Ann R Coll Surg Engl. 2007;89(7):672-4.

5. Vasilescu C, Trandafir B. Current problems in surgical oncology 2. A lesson from Japan. D2 lymphadenectomy in gastric cancer. Chirurgia (Bucur). 2011;106(2):163-70.

6. Maruyama K, Okabayashi K, Kinoshita T. Progress in gastric cancer surgery in Japan and its limits of radicality. World J Surg. 1987;11(4):418-25.

7. Bonenkamp JJ, Hermans J, Sasako M, van de Velde CJ, Welvaart $\mathrm{K}$, Songun I, et al. Extended lymph-node dissection for gastric cancer. N Engl J Med. 1999;340(12):908-14.

8. Cuschieri A, Weeden S, Fielding J, Bancewicz J, Craven J, Joypaul $\mathrm{V}$, et al. Patient survival after D1 and D2 resections for gastric cancer: long-term results of the MRC randomized surgical trial. Surgical Co-operative Group. Br J Cancer. 1999;79(9-10):1522-30.

9. Degiuli M, Sasako M, Ponti A, Vendrame A, Tomatis M, Mazza C, et 
al. Randomized clinical trial comparing survival after D1 or D2 gastrectomy for gastric cancer. Br J Surg. 2014;101(2):23-31.

10. Degiuli M, Sasako M, Ponti A, Italian Gastric Cancer Study G. Morbidity and mortality in the Italian Gastric Cancer Study Group randomized clinical trial of D1 versus D2 resection for gastric cancer. Br J Surg. 2010;97(5):643-9.

11. Songun I, Putter H, Kranenbarg EM, Sasako M, van de Velde CJ. Surgical treatment of gastric cancer: 15-year follow-up results of the randomised nationwide Dutch D1D2 trial. Lancet Oncol. 2010;11(5):439-49.

12. Popovici A, Steriu L, Zgarbura R, Posea R, Stancescu M. Neoplasm of the inferior gastric pole. Chirurgia (Bucur). 1993;42(1):23-37.

13. Setlacec D, Popovici A, Medianu D, Sosoiu S, Ivan L. [Neoplasm of the superior gastric pole]. Rev Chir Oncol Radiol 0 R L Oftalmol Stomatol Chir. 1985;34(4):257-70.

14. Popovici A, Popescu I, Ionescu M, Vasilescu C, Ciurea S, Tonea A, et al. [Palliative total gastrectomy in advanced malignancies of the stomach]. Chirurgia (Bucur). 2001;96(2):147-51.

15. Vasilescu C, Herlea V, Tidor S, Ivanov B, Stanciulea 0 , Manuc M, et al. [D2 lymph node dissection in gastric cancer surgery: long term results--analysis of an experience with 227 patients]. Chirurgia (Bucur). 2006;101(4):375-84.

16. Procopiuc L, Tudor S, Manuc M, Diculescu M, Vasilescu C. Open vs robotic radical gastrectomy for locally advanced gastric cancer. Int J Med Robot. 2016;12(3):502-8.

17. Procopiuc L, Tudor S, Manuc M, Diculescu M, Vasilescu C. Robotassisted surgery for gastric cancer. World J Gastrointest Oncol. 2016;8(1):8-17.

18. Vasilescu C, Popa M, Tudor S, Manuc M, Diculescu M. Robotic surgery of locally advanced gastric cancer -- an initial experience. Acta Chir Belg. 2012;112(3):209-12.

19. Vasilescu C, Procopiuc L. Robotic surgery of locally advanced gastric cancer: a single-surgeon experience of 41 cases. Chirurgia (Bucur). 2012;107(4):510-7.

20. Vasilescu C. D3 lymphatic dissection in surgery for gastric cancer. Chirurgia (Bucur). 2007;102(3):327-30.

21. de Manzoni G, Verlato G, Guglielmi A, Laterza E, Genna M, Cordiano C. Prognostic significance of lymph node dissection in gastric cancer. Br J Surg. 1996;83(11):1604-7.

22. Siewert JR, Bottcher K, Stein HJ, Roder JD. Relevant prognostic factors in gastric cancer: ten-year results of the German Gastric Cancer Study. Ann Surg. 1998;228(4):449-61.

23. Roukos DH, Lorenz M, Encke A. Evidence of survival benefit of extended (D2) lymphadenectomy in western patients with gastric cancer based on a new concept: a prospective long-term follow-up study. Surgery. 1998;123(5):573-8.

24. Roviello F, Marrelli D, Morgagni P, de Manzoni G, Di Leo A, Vindigni $C$, et al. Survival benefit of extended D2 lymphadenectomy in gastric cancer with involvement of second level lymph nodes: a longitudinal multicenter study. Ann Surg Oncol. 2002;9(9): 894-900.

25. Marrelli D, De Franco L, ludici L, Polom K, Roviello F. Lymphadenectomy: state of the art. Transl Gastroenterol Hepatol. 2017;2:3.

26. Kinoshita T, Maruyama K, Sasako M, Okabayashi K. Lymph node issection around the splenic artery for gastric cancer - a comparative study of pancreatectomy and pancreas-preserving operation. Nihon Geka Gakkai Zasshi. 1992;93(2):128-32.

27. Galizia G, Lieto E, De Vita F, Castellano P, Ferraraccio F, Zamboli A, et al. Modified versus standard D2 lymphadenectomy in total gastrectomy for nonjunctional gastric carcinoma with lymph node metastasis. Surgery. 2015;157(2):285-96.
28. Lee KY, Noh SH, Hyung WJ, Lee JH, Lah KH, Choi SH, et al. Impact of splenectomy for lymph node dissection on long-term surgical outcome in gastric cancer. Ann Surg Oncol. 2001;8(5):402-6.

29. Wang Q, Dang T, Meng X, Li K, Ren W, Ma X, et al. Is concomitant splenectomy necessary in radical gastric cancer surgery? A systematic review and meta-analysis. Asia Pac J Clin Oncol. 2018.

30. Mahar AL, Qureshi AP, Ottensmeyer CA, Chetty R, Pollett A, Coburn $N G$, et al. Improving the quality of processing gastric cancer specimens: the pathologist's perspective. J Surg Oncol. 2010; 101(3):195-9.

31. Boscaiu MD, Dragomir, M., Trandafir B.; Herlea V.; Vasilescu C. Should surgical ex vivo lymphadenectomy be a standard procedure in the management of patients with gastric cancer? European Surgery. 2018;50(4):169-76.

32. Ciesielski M, Kruszewski WJ, Walczak J, Szajewski M, Szefel J, Wydra J, et al. Analysis of postoperative morbidity and mortality following surgery for gastric cancer. Surgeon volume as the most significant prognostic factor. Prz Gastroenterol. 2017;12(3): 215-21.

33. Yu W, Yun YK, Whang I, Choi GS. The surgeon's expertise-outcome relationship in gastric cancer surgery. Cancer Res Treat. 2005; 37(3):143-7.

34. Lee JH, Ryu KW, Lee JH, Park SR, Kim CG, Kook MC, et al. Learning curve for total gastrectomy with D2 lymph node dissection: cumulative sum analysis for qualified surgery. Ann Surg Oncol. 2006;13(9):1175-81.

35. Parikh D, Johnson M, Chagla L, Lowe D, McCulloch P. D2 gastrectomy: lessons from a prospective audit of the learning curve. $\mathrm{Br} \mathrm{J}$ Surg. 1996;83(11):1595-9.

36. Wu CW, Hsiung CA, Lo SS, Hsieh MC, Chen JH, Li AF, et al. Nodal dissection for patients with gastric cancer: a randomised controlled trial. Lancet Oncol. 2006;7(4):309-15.

37. Mahar AL, McLeod RS, Kiss A, Paszat L, Coburn NG. A systematic review of the effect of institution and surgeon factors on surgical outcomes for gastric cancer. J Am Coll Surg. 2012;214(5):860-8 e12.

38. Mukai Y, Kurokawa Y, Takiguchi S, Mori M, Doki Y. Are treatment outcomes in gastric cancer associated with either hospital volume or surgeon volume? Ann Gastroenterol Surg. 2017;1(3):186-92.

39. Claassen YHM, van Amelsfoort RM, Hartgrink HH, Dikken JL, de Steur WO, van Sandick JW, et al. Effect of Hospital Volume With Respect to Performing Gastric Cancer Resection on Recurrence and Survival: Results from the CRITICS Trial. Ann Surg. 2018.

40. Lustosa SA, Saconato H, Atallah AN, Lopes Filho Gde J, Matos D. Impact of extended lymphadenectomy on morbidity, mortality, recurrence and 5-year survival after gastrectomy for cancer. Metaanalysis of randomized clinical trials. Acta Cir Bras. 2008; 23(6):520-30.

41. Memon MA, Subramanya MS, Khan S, Hossain MB, Osland E, Memon B. Meta-analysis of D1 versus D2 gastrectomy for gastric adenocarcinoma. Ann Surg. 2011;253(5):900-11.

42. Jiang L, Yang KH, Guan QL, Zhao P, Chen Y, Tian JH. Survival and recurrence free benefits with different lymphadenectomy for resectable gastric cancer: a meta-analysis. J Surg Oncol. 2013; 107(8):807-14.

43. El-Sedfy A, Dixon M, Seevaratnam R, Bocicariu A, Cardoso R, Mahar A, et al. Personalized Surgery for Gastric Adenocarcinoma: A Meta-analysis of D1 versus D2 Lymphadenectomy. Ann Surg Oncol. 2015;22(6):1820-7.

44. Xirasagar S, Lien YC, Lin HC, Lee HC, Liu TC, Tsai J. Procedure volume of gastric cancer resections versus 5 -year survival. Eur $\mathrm{J}$ Surg Oncol. 2008;34(1):23-9. 